\title{
Rapid Detection and Differentiation between Sheep Pox and Goat Pox Viruses by Real-Time qPCR and Conventional PCR in Sheep and Goats in Egypt
}

\author{
Gamil SG Zeedan $^{1 *}$, Ayman H. Mahmoud ${ }^{2}$, Abeer M. Abdalhamed ${ }^{1}$, Alaa A. Ghazy ${ }^{1}$ and Khaled A. Abd EL-Razik ${ }^{3}$ \\ ${ }^{I}$ Parasitology and Animals Diseases Department, National Research Centre,33 Bohouth St., Dokki, Giza, P.O. box 12622, Egypt \\ ${ }^{2}$ Biotechnology Department, Animal health Institute (AHRI), Agricultural Research Center (ARC), Nadi El-said Street, Dokki Giza \\ ${ }^{3}$ Reproduction Diseases Department, National Research Centre, 33 Bohouth St., Dokki, Giza, P.O. box 12622, Egypt \\ *Corresponding author's Email: gamilzee@yahoo.com ; iDORCiD: 0000-0002-2723-542X
}

\begin{abstract}
Capri Pox Virus (Ca PV) is the causative agent of important diseases in sheep and goats with severe socio-economic impact. Sheep Poxvirus (SPPV), Goat Poxvirus (GTPV) and Lumpy Skin Disease Virus (LSDV) are three members of the Capripox virus genus of Poxviridae family, which infect sheep, goats, and cattle, respectively. A rapid diagnostic assay for Ca PV by using conventional PCR RNA polymerase gene RP030 and real-time qPCR would be useful for disease surveillance, detection and differentiation of $\mathrm{Ca} \mathrm{PV}$ in clinical and subclinical samples for management and treatments of outbreaks. The present study aimed to detect and identify Ca PV (SPPV and GTPV) in natural, infected scabs biopsy samples, which were collected from sheep and goats in different governorates in 2017 during outbreaks in Egypt using the conventional PCR RNA polymerase gene RP030 gene-based and RealTime qPCR fluorescent-based. We collected eighty scabs from clinically affected animals (54 sheep and 26 goats) that were vaccinated in Chorio-Allantoic-Membranes (CAM) from 10-days-old embryonated-chicken eggs. The positive CAM showed pock lesions, which were observed with a thickening of the membrane after 2-3 passages post samples inoculation, and harvested positive CAMs, which were determined by Agar Gel Precipitation Test (AGPT), Counter Immune Electrophoresis (CIE), and conventional PCR and real time qPCR were examined for the presences of Ca PVs. DNA extraction from clinical samples and positive CAM with pox lesions using DNA slandered references extraction kits compared to novel modification method (Microwave extraction). The PCR based RPO30 gene and the real-time qPCR showed 15 positive with percentage $27.77 \%$ in 54 sheep and 3 positive with percentage $12.5 \%$ in 26 goats. Although AGPT and CIE led to lower results than molecular methods, the findings indicated 11 and 13 positive samples out of 54 sheep as well as 1 and 2 positive samples out of 26 scab biopsy samples derived from goats, respectively. However, they are useful for early confirmation of positive Ca PVs in low-income countries. PCR based RNA polymerase gene RP030 gene and real-time-PCR considered sensitive, rapid, and reliable methods for differentiating SPPV and GTPV from AGPT and CIE in CAM or in clinical samples without further isolation and propagation in embryonated-chicken eggs. The novel microwave method used to isolate high quality of DNA extracted from infected skin biopsy with SPPV and GPPV with no further purification steps required. It was done in 3 minutes only. The results of the current study confirmed that the suitability of the PCRbased RNA polymerase gene RP030 gene is suitable for differentiating between SPPV and GTPV; in one PCR run; without any post-processing steps.
\end{abstract}

Key words: Capripox virus, DNA extraction, Goat pox, KOH extraction method, Real-Time qPCR, RPO30, Sheep pox

\section{INTRODUCTION}

Sheep pox and goat pox are contagious viral diseases of small ruminants. In endemic areas the affected animals showed mild clinical symptoms, but were fatal to newly introduced animals (Lamien et al., 2011). The current criterion used for classification of CaPVs based on animal species from which the virus was isolated, LSDV from cattle, GTPV from goats and SPPV from sheep, respectively (Santhamani et al., 2013). The Capri poxvirus was endemic to the Middle East, including Egypt (Manjunathareddy et al., 2017; OIE, 2017; Lafar et al., 2020). SPPV and GTPV are spread directly or indirectly through aerosols and/or close contact with infected animals (Zangana and Abdullah, 2013; Manjunathareddy et al., 2017;Abd-Elfatah et al., 2019). Pox disease characterized by fever, appearance of papules, pustules, and scab in checks, lips, nostrils, medial part of the thigh and under the tail usually remitted and cured within 5-6 weeks (Sharma et al., 2018). The isolation of Ca PV on CAM from ECE is considered to be a preliminary diagnostic test by developing characteristic pock lesions CAM (Bhanuprakash et al., 2010; Sharma, 2019). Interestingly, the virus was host specific, even sheep and goats were reared together. The SPPV only infected sheep and GTPV only infected goats (Gelaye et al., 2013). Electron microscopy (EM) cannot differentiate Ca PV infection from the affected sheep and goat based on morphological characterization in infected tissue biopsy samples. PCR was considered a rapid, sensitive technique for the detection and differentiation of SPPV from GTPV (Gelaye et al., 2013 ; Zeedan et al., 2019). Several suitable 
molecular assays have been developed for the detection of CaPVs (Zeedan et al., 2014; Abdallah et al., 2018). Most of these tests were restricted to detect only one viral species (Tassew et al., 2018; Gelaye and Lamien, 2019). RPO 30 gene-based PCR depended on the presence of RPO30 gene encoding the 30 kilo Dalton (kDa) RNA polymerase subunit in Ca PVs (Assefa, 2017). The present study aimed to detect and differentiate sheep pox virus from goat pox virus infected small ruminants during the outbreak of pox disease in 2017 by using conventional PCR RPO30 gene based and real-time qPCR.

\section{MATERIALS AND METHODS}

\section{Ethical approval}

The research was ethically conducted and approved by the Medical Research Ethical Committee Research, the National Statement on Ethical Conduct in Human and animals Research at National Research Centre in Egypt under registration number 19149 and the International Animal Ethics Committee in Egypt (Fahmy and Gaafar, 2016) and in accordance with local laws and regulations.

\section{Sample collection}

A natural sheep pox disease, which usually shows clinical symptoms in sheep and goat flocks which had not vaccinated with SPPV in the past, was recorded in different governorates (Beni-suef, El-Fayoum, Giza, Monifia, Sharkia and El-Menia) in Egypt in 2017. Clinical signs in sporadic cases of sheep and goat related to skin lesions such as papules, nodules and scab's formation on an area free of wool and hair, which led to a suspected infection with pox disease. Eighty skin biopsy samples from crusted scabs lesions were collected from 80 affected sheep and goat and were stored at $-40^{\circ} \mathrm{C}$ until use.

\section{Preparation biopsy samples}

According to 3, 15 (OIE, 2017) 10\% suspension of suspicious tissue samples (papules and scabs) prepared in Phosphate Buffer Saline (PBS) containing antibiotic (penicillin (100 U/ml), streptomycin $(100 \mu \mathrm{g} / \mathrm{ml})$, neomycin $(2.5 \mathrm{mg} / \mathrm{ml})$ and nystatin $(50 \mathrm{U} / \mathrm{ml}))$. The samples were ground with sterile sand in a mortar. The homogenized suspension was frozen-thawed three times and then partially clarified by centrifuging at 5000 rpm for 15 minutes to remove tissue depressed and then stored at $-40^{\circ} \mathrm{C}$ till used.

\section{Virus propagated in embryonated chicken eggs}

Approximately 10-12 specific pathogen-free production (SPF) of embryonate chicken egg (ECE) were purchased from Specific pathogen-free production (SPF) Kaom-Oshan Company, El-Fayoum Egypt. The Chorio-Allantoic Membrane (CAM) protocol for inoculation of the virus for virus isolation in CAM, described in (Gelaye and Lamien, 2019) by using the artificial air sac route. Briefly- Embryos of 10 to 12 days were candled for embryos viability. An area was marked and disinfected approximately $1 / 4$ inch below and parallel to the base of the air cell, then at this point a hole was drilled, and another hole was drilled directly on the top of the air cell. The embryo was placed horizontally with the hole facing up. Holding the embryo in the same position and using a rubber bulb, air was drawn out of the air cell by placing the bulb over the hole at the top of the embryo. This negative pressure created the artificial air cell by pulling down the CAM. A fine needle was inserted into air sac about $1 / 8$ inch and $0.1 \mathrm{ml}$ inoculum released. The embryo was placed horizontally for 24 hours then returned to upright position. The holes in the inoculated eggs were sealed with molten wax and incubated for five days at $37^{\circ} \mathrm{C}$ in an egg incubator. After 5-6 days of inoculation, eggs were harvested from the embryo. Both putative SPPV and GTPV were inoculated on CAM and identified by PCR and RT-PCR.

\section{Counterimmunoelectrophoresis}

An improvement on the precipitation method was described with the development by Page et al. (2015). The antigen and their specific antibody move through the gel and can be accelerate by applying an electrical current, and precipitation occurs within a few hours (Aguilar-Torres et al 1976)

\section{Agar gel precipitation test}

This method was performed with minor modifications to the methods of Zeedan et al. (2015). 1.5 gram agarose (Difco) and 1.5 gram glycine were added to $100 \mathrm{ml}$ distal water containing 0.85 gram sodium chloride. The mixture was boiled in water bath to dissolve the agarose and left at room temperature until $45^{\circ} \mathrm{C}$ was reached, and then poured in 5 $\mathrm{cm}$ diameter Petri dishes in diameter to obtain an agar thickness of $2 \mathrm{~mm}$. The plates were allowed to solidify at room temperature. After the agarose had solidified of in Petri dishes, 7 wells with a diameter of $3 \mathrm{~mm}$ in were made by using metal cutter. The central well was filled with (Positive control SPPV or GTPV) and 4 peripheral wells were filled with tested serum samples. The upper and lower peripheral wells received positive and negative serum as controls. Then 
incubated at room temperature in a humidity chamber, and checked every 12, 24, 48 and 72 hours until lines of precipitation were detected.

\section{DNA extraction}

\section{Microwave irradiation}

First, DNA was extracted from the collected CAMs with pock lesions and from clinically collected scabs biopsy samples by using the QIAamp DNA extraction kit (QIAGEN). The three SOPs, fresh whole blood, heparinized blood samples in heparinized tubes, small amounts of skin biopsy samples in $30 \mu \mathrm{lBS}$. Ten $\mu$ l of blood were transferred into $0.5 \mathrm{ml}$ tubes adjusted microwave at $800 \mathrm{~W}$ for 2 minutes until precipitated and condensed droplets were visible on and retrievable from the tube walls. One $\mu \mathrm{l}$ of the clear DNA was taken from the walls or from lid of the tube according to Melendez (2016). Alternatively, for enduring storage, $30 \mu \mathrm{l}$ of sterile phosphate buffer saline (PBS) were added to the irradiated sample. In particular, smaller tubes can break and be destroyed by air expansion and thus carry the risk of contamination (Seesui et al., 2018; Yuan et al., 2019)

\section{Polymerase chain reaction}

The polymerase chain reaction (PCR) protocol described by Kumar et al. (2016) and Assefa et al. (2018), which was based on the RPO30 gene to differentiate GTPV from SPPV, was used. The test was carried out in a $25 \mu$ capacity PCR tube.

Table 1. Preparation of PCR reaction tube component

\begin{tabular}{|c|c|}
\hline Component & Volume/Reaction \\
\hline Maxima Green PCR Master Mix (2x premix) & $12.5 \mu 1$ \\
\hline Nuclease free water & $8.5 \mu \mathrm{l}$ \\
\hline $\begin{array}{l}\text { Forward primer }(20 \text { pmol }) \text { RNA Pol } \\
\text { F 5'-TCTATGTCTTGATATGTGGTGGTAG-3, }\end{array}$ & $1 \mu 1$ \\
\hline $\begin{array}{l}\text { Reverse primer ( } 20 \text { pmol) RNA } \\
\text { Pol 5'-AGTGATTAGGTGGTGTATTATTTTCC-3' }\end{array}$ & $1 \mu 1$ \\
\hline Samples extracted DNA included + ve and - ve control & $2 \mu 1$ \\
\hline Total & $25 \mu 1$ \\
\hline
\end{tabular}

Table 2. PCR amplification conditions using RNA polymerase gene primers PO30

\begin{tabular}{lcccccc}
\hline \multicolumn{6}{c}{ PCR amplification conditions } \\
\hline Gene & $\begin{array}{c}\text { Primary } \\
\text { denaturation }\end{array}$ & $\begin{array}{c}\text { Secondary } \\
\text { denaturation }\end{array}$ & $\begin{array}{c}\text { Main Cycle for amplification } \\
\text { Annealing }\end{array}$ & Extension & No. of cycles & Final extension \\
\hline Sheep pox RNA polymerase & 95 & 95 & 55 & 72 & 40 & 72 \\
PO30 & $4 \mathrm{~min}$ & $30 \mathrm{sec}$ & $30 \mathrm{sec}$ & $30 \mathrm{sec}$ & $\ldots$ & $5 \mathrm{sec}$ \\
\hline
\end{tabular}

The amplification conditions were initial denaturation, followed by 40 cycles of denaturation, annealing and extension and final extension at $72^{\circ} \mathrm{C}$ for 5 min in a thermocycler (Biorad).

\section{Agarose gel electrophoreses}

It was performed with modification by (Zeedan et al., 2019). $10 \mu \mathrm{l}$ PCR product samples were mixed with amplified reference pox positive control with loaded dye solution and loaded in $2 \%$ agarose gel in TAE (Tris/ Acetate/ EDTA) buffer containing $0.5 \mathrm{ul}$ of ethidium bromide , $100 \mathrm{bp}$ DNA-marker ladder (Gendirect). Separate the products at 100 volts for 60 minutes and visualize using a UV Transilluminator according to (Sambrook et al., 1989).

\section{Real-time-qPCR assay to detect sheep and goat pox virus}

Real-Time qPCR was used to prepare a reaction mixture according to the manufacturer's guidelines. To detect and differentiate SPPV dtec-qPCR target species were used as a mono-dose of ready prepared dtec-qPCR (contains a dehydrated mixture of specific primers and labeled probe, dNTPs, BSA, polymerase and buffer at optimal concentrations, 96 dtec-qPCR 96 reaction). While, GTPV was used to target dtec-qPCR-mix species (contains a mixture of specific forward/reverse primers and probe, lyophilized at optimal concentration after synthesis, 100 dtec-qPCR 96 reaction) with probe and DNA template for internal control of fluorogenic minor groove-binding TaqMan probe (5' CAATGGGTAAAAGATTTCTA 3'; labeled with 6-carboxyfluorescein and a no fluorescent quencher) (200 nm) were included in each reaction mixture. Sample template $(2.5 \mu \mathrm{l})$ was added to the reaction mixture in a 25 - $\mu$ l reaction tube. The cycling conditions consisted of an initial denaturation at $95^{\circ} \mathrm{C}$ for 120 seconds, followed by 45 amplification cycles 
$\left(95^{\circ} \mathrm{C}\right.$ for $2 \mathrm{~s}$ and $60^{\circ} \mathrm{C}$ for $\left.60 \mathrm{~s}\right)$. The assay was run with a Bio-Rad Real Time Thermocycler. Positive and negative controls were included with each set of reaction mixtures.

\section{Statistical analysis}

Statistical analysis of performance of the SPPV and GTPV real-time PCR assay was compared to CIE and/or conventional PCR agarose gel based on the detection of Ca PV infected sheep and goats in clinical and scab biopsy samples of the percentage and accurate Fisher's test at $95 \%$ based on the confidence interval $(p \leq 0.05)$ and used the Statistics Package for the Social Sciences (SPSS, version 16, Chicago, USA).

\section{RESULTS}

Harvested positive CAMs with characteristic pock lesions for the passage of sheep pox virus were characterized by the opaque thickening and edema of the membrane, and hemorrhage was also observed in CAM. The preliminary positive resulted from sheep and goat scabs biopsies on the CAM of ECE were 13 out from 56 from sheep and 2 out from goat samples. While the negative sample showed no pathological changes, CAM with SPPV and GTPV after 5 days of inoculation, as shown in table 3 , also showed pathological changes after the $3^{\text {rd }}$ passage in ECE. Positive pock lesion samples were prepared for antigen detection, characterization and DNA extraction by a new modified microwave extraction method compared to a standard extraction method. DNA extraction was achieved from various sources, including supernatant from collected clinical samples and positive CAM with pock lesion samples. Microwave tubes 0.5 $\mathrm{ml}$ containing $10 \mu \mathrm{l}$ of supernatant within a microwave led to boiling and partial desiccation of the sample and to the formation of vapour, tissue-free condensed vapour contained the nucleic acid on the micro-tube walls and appropriate templates for further lid processing both in conventional standard PCR and in Real Time PCR assays.

Table 3. Detection of sheep and goat pox viruses by pock lesion on CAM of ECE and PCR based on PRO30 from skin biopsy samples from small ruminants in different governorates (Beni-suef, El-Fayoum, Giza, Monifia, Sharkia and ElMenia) in Egypt during sheep and goat pox outbreak on 2017.

\begin{tabular}{|c|c|c|c|c|}
\hline \multirow[t]{2}{*}{ Small ruminants } & \multirow{2}{*}{$\begin{array}{c}\text { Egg inoculation CAM of ECE } \\
10 \text { days old \% +ve }\end{array}$} & \multicolumn{2}{|c|}{$\begin{array}{c}\text { Confirmation positive CAM by PCR } \\
\text { based on PRO30 \% +ve }\end{array}$} & \multirow{2}{*}{$\begin{array}{c}\text { Results confirmed by } \\
\text { PCR }\end{array}$} \\
\hline & & C-PCR & Real-Time -PCR & \\
\hline Sheep scab biopsy samples & $13 / 54(24.07 \%)$ & $13 / 13(100 \%)$ & $13 / 13(100 \%)$ & SPPV \\
\hline Goat scab biopsy samples & $2 / 26(7.69 \%)$ & $2 / 2(100 \%)$ & $2 / 2(100 \%)$ & GTPV \\
\hline Control positive SPPV & $1 / 1(100 \%)$ & $1 / 1(100 \%)$ & $1 / 1(100 \%)$ & $\mathrm{SPPV}+$ ve C \\
\hline Control negative PBS PH 7.2 & $0 / 1(0.00 \%)$ & $0 / 1(0.00 \%)$ & $0 / 1(0.00 \%)$ & PBS -ve C \\
\hline
\end{tabular}

$\%+\mathrm{ve}=$ percent of positive samples

\section{Analytical sensitivity}

The sensitivity of the cell Culture PCR (C -PCR) and real-time qPCR assays used for the microwave extraction method was determined on the basis of serial two fold dilution /100 $\mu$ l of positive SPPV at titer 10 5.5 EID50/ ml. DNA was extracted from all dilutions applying standard extraction method (Qi amp Qigean) and the microwave extraction method was detected at a dilution of $1 / 128$ to $1 / 512$. 


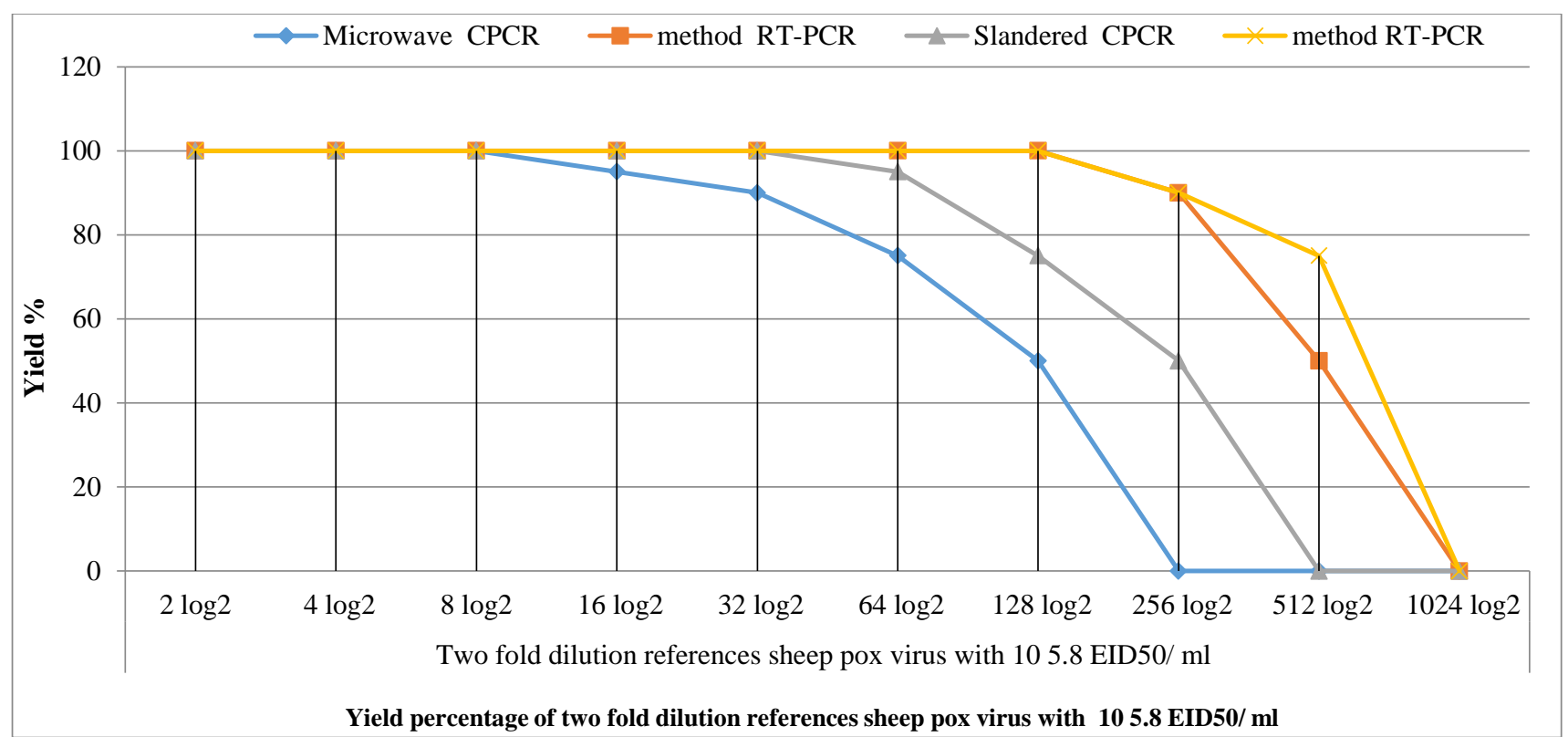

Figure 1. Different extraction methods used to SPPV DNA amplification by conventional PCR and Real-Time PCR

Table 4 showed that the sensitivity of CIE compared to AGPT was determined by screening 80 sheep and goats scabs biopsy samples collected from naturally infected animals during the sheep pox outbreak in 2017 for the presence of precipitins. While only 12 of the 80 samples were positive by the AGPT, the CIE gave positive 15 out of 80 sheep and goat samples, as shown in table 4. The CIE was better than the AGPT for detection of SPPV and GTPV in skin lesions of sheep and goats. Examination of the scab biopsies of sheep and goat using RPO30 gene based PCR showed that 18 out of 80 samples were positive (15 sheep and 3 goats). The control positive of sheep and goat pox was included. The appropriate sheep pox DNA fragment is $151 \mathrm{bp}$ and for GTPV is $172 \mathrm{bp}$ using RPO30 gene-based PCR were obtained. The results revealed no cross infection in any of the tested animal samples (Table 4 and figure 2).

Table 4. Comparison of different diagnostic methods for the detection of sheep pox virus (SPV) and goat pox virus (GTPV) in different governorate in Egypt on 2017

\begin{tabular}{|c|c|c|c|c|c|c|c|c|c|c|c|c|c|}
\hline \multirow{2}{*}{$\begin{array}{l}\text { Small } \\
\text { ruminants }\end{array}$} & \multirow{2}{*}{$\begin{array}{c}\text { No. of scabs } \\
\text { biopsy } \\
\text { samples }\end{array}$} & \multicolumn{3}{|c|}{ AGPT } & \multicolumn{3}{|c|}{ CIE } & \multicolumn{3}{|c|}{ C PCR } & \multicolumn{3}{|c|}{ Real Time PCR } \\
\hline & & $+v e$ & -ve & $\%+v e$ & $+v$ & -ve & $\%+v$ & $+v$ & -ve & $\%+v$ & $+v$ & -ve & $\%+v e$ \\
\hline Sheep & 54 & 11 & 43 & 20.37 & 13 & 41 & 24.07 & 15 & 39 & 27.77 & 15 & 39 & 27.77 \\
\hline Goat & 26 & 1 & 25 & 3.8 & 2 & 24 & 7.69 & 3 & 21 & 11.53 & 3 & 21 & 11.53 \\
\hline Total & 80 & 12 & 68 & 15 & 15 & 65 & 18.75 & 18 & 60 & 22.5 & 18 & 60 & 22.5 \\
\hline
\end{tabular}

$\%+\mathrm{ve}=$ percent of positive samples

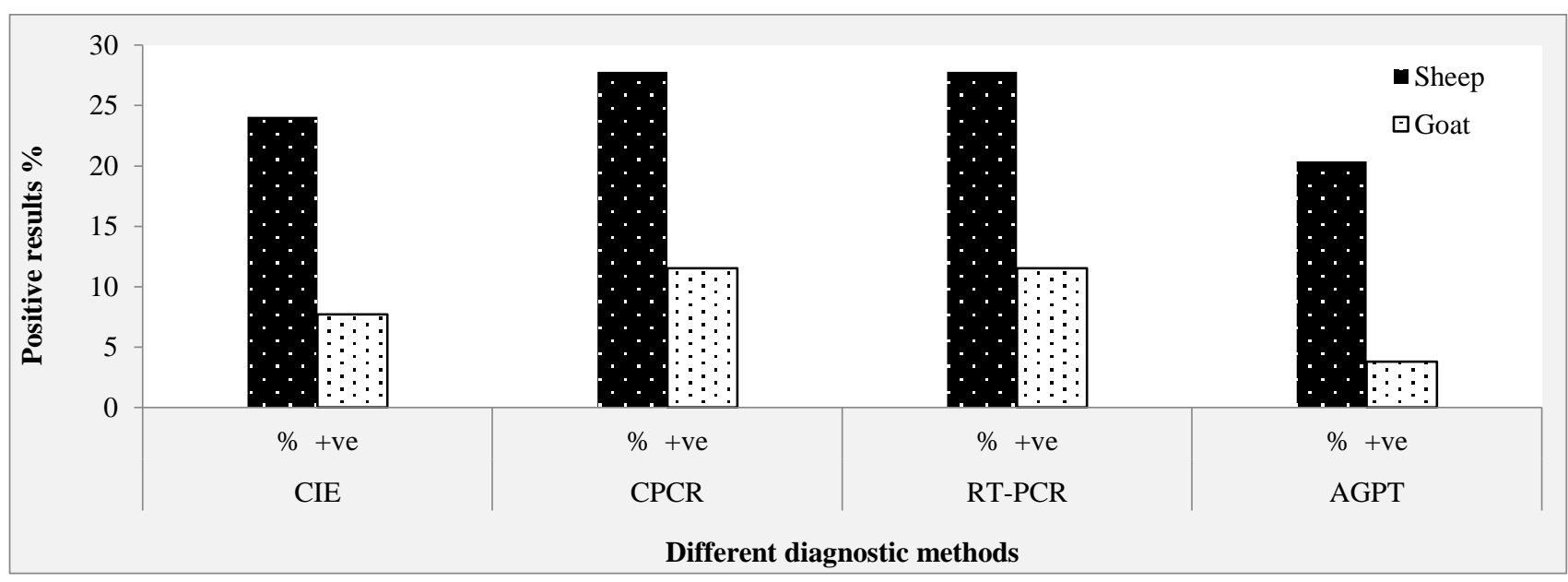

Figure 2. Positive percentage results for scab biopsy samples of suspected sheep and goat infected with Pox virus, which were examined using different diagnostic methods. $\%+$ ve CIE $=$ Positive percent of counter immune electrophoresis, $\%$ +ve c-PCR = Positive percent of conventional PCR, \% +ve RT-PCR $=$ Positive percent of Real-Time PCR, \% +ve AGPT $=$ Positive percent of agar gel precipitation test. $\%+v e=$ percent of positive samples 


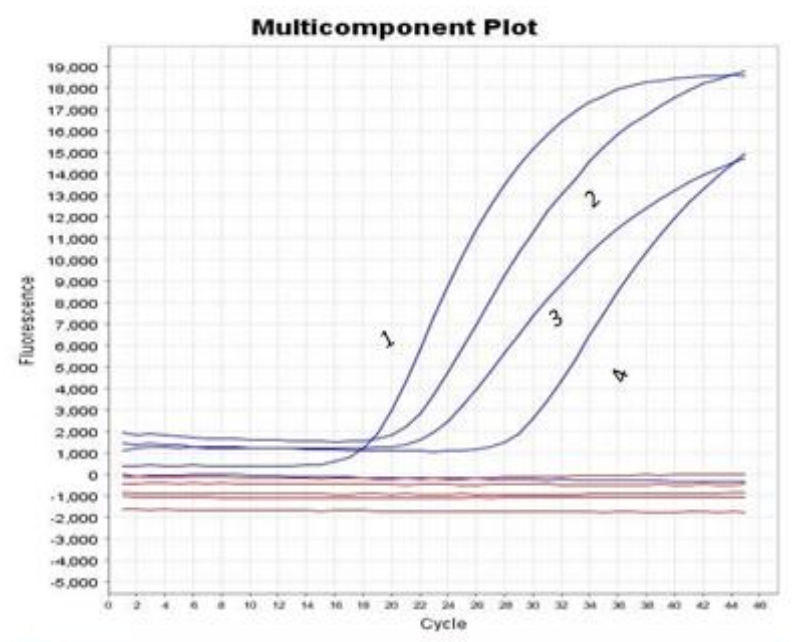

A

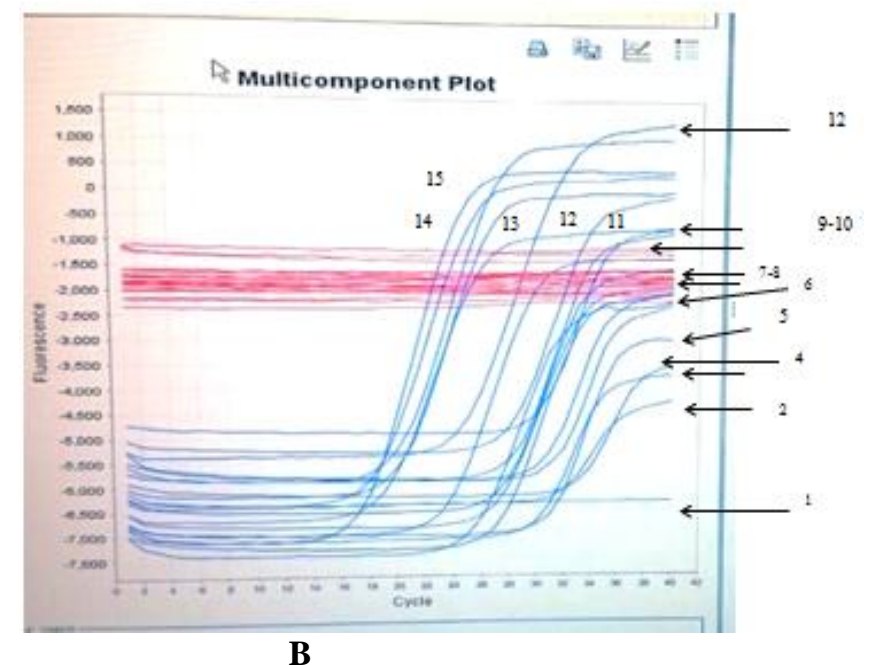

B

Figure 3. A) Amplification plot showed a positive control, and $\mathrm{Ct} 2, \mathrm{Ct} 1$ and $\mathrm{Ct} 3$ are positive tested samples for DNA extracted from a biopsy skin lesion. Ct 4 showed positive DNA extracted from infected CAM with pathogenic pock lesion for SPPV. Ct = DNA-free negative control (graphic generated by ES Equant). 3B) Amplification plot showed negative results ( $\mathrm{Ct}$ from 1 to 8 ) and showed negative DNA extracted from sheep and goat skin lesion. Ct 9 to12 showed positive results for GTP positive CAM with pathogenic pock lesion from GTPV. Ct 12 to15 showed positive results for SPPV positive CAM with pathogenic pock lesion of SPPV

\section{DISCUSSION}

Laboratories had encountered problems with the use of commercial extraction kits that results from interference tissues for DNA extraction. Direct DNA amplification by whole blood or tissue biopsy and cell culture was very difficult to achieve. Cheap and simple methods had been described in which heat denaturation or chemical lysis by KOH, an Eiken boiling-spin method and a water bath or thermoblock, could be used for DNA extraction in field and laboratory applications (Melendez, 2016; Seesui et al., 2018). The present study showed an optimized microwave extraction method as an alternative to slandered commercial DNA extraction used for conventional and Real-Time PCR to detect and differentiate between SPPV and GTPV in clinical samples collected during the 2017 Egyptian outbreak (Table 3 and figure 2). The microwave extraction method was tested for sensitivity by repeated serial dilutions using commercially available kit as shown in figure 1. The DNA was successfully extracted from scabs tissue biopsy samples in less than 3 minutes and no additional further chemicals were required for isolation or purification. Our study demonstrates that DNA was extracted from blood samples, tissue scabs biopsy samples and CAM tissue samples (Kumar et al., 2016; Assefa, 2017). SPPV and GTPV could not be distinguished by serological assays due to close antigenic relationships (Zeedan et al., 2014; Shehbaz and Hassan, 2017). Due to the low sensitivity and specificity, the serological tests were replaced by PCR. The diagnosis of sheep and goat pox virus was often described clinically only as sheep pox or goat pox, respectively followed by virus isolation on cell cultures with further confirmation by PCR (Sambrook et al., 1989; Al-Shabebi et al., 2014;Fentie et al., 2017). The classification of Ca PVs based on the animal species from which the virus was isolated suggested that the Ca PVs were strictly host-specific and these results concurred with (Shehbaz and Hassan, 2017; Abd-Elfatah et al., 2019). In 2017, sheep and goat in different governorates of Egypt showed different clinical signs such as increasing body temperature, nasal lacrimation discharges and scabs on head, face, nostrils, oral and lips, as well as multiple nodules on medial aspect of thigh and under the tail similar to finding the outbreak of sheep pox recorded by (Mahmoud and Khafagi, 2016; Atalla and Alzuheir, 2019). The present study showed the PCR was more useful than conventional methods as isolation and AGPT and it was a perfect tool for viral identification and differentiation of Capripox based on RPO 132 gene, and these findings were similar to outbreak of SPPV (Mahmoud and Khafagi, 2016; Atalla and Alzuheir, 2019). A comparison between AGPT and CIE revealed deviations in the results of the two diagnostic techniques which sheep (11 and 13/56) and goats (1 and 2/26) presented from the previous results. The CIE method was more sensitive than AGPT diagnostic methods for detection of SPPV and GTP. For the differentiation of SPPV and GTPV by PCR based RPO30 genes, which had a 21 -nucleotide deletion in the 5' end in SPPV and were not present in GTPV. The present study was showed that SPPVs and GTPVs could be detect and differentiate by PCR and Real-Time PCR and that the screening of samples was possible in a short time compared to time required to isolate viruses in ECE. Examination of 80 samples with conventional PCR, identified a total 18 positive samples from (15 sheep and 3 goats), as shown in table 2 and figure 2. RPO30 gene of SPPV had a 21-nucleotide deletion at the 5' end compared to GTPV, the amplicon size of SPPV was $152 \mathrm{bp}$, while the amplicon size of GTPV was $172 \mathrm{bp}$ according to Cohen et al. (1971), Yan et al. (2012), Page et al. (2015), Zeedan et al. (2015), and Yang et al. (2019). The present study revealed that the RPO30 gene based PCR and real-time qPCR were successfully detected and differentiated sheep pox and goat pox in field clinical samples in sheep and goat as shown in table 4 and in figure $3 \mathrm{~A}$ 
and B according to (Bhanuprakash et al., 2011; Gelaye et al., 2013). Real-Time PCR and RPO30 gene-based PCR were accurate and rapid detection of SPPV and GTPV. The present result provided meaningful results for the identification and differentiating of SPPV from GTPV in clinical biopsy samples collected during outbreak sheep and goat in Egypt in 2017 without isolation of virus requirement.

\section{CONCLUSION}

The Real-Time and conventional PCR based PRO30 gene had been successfully used to differentiate and identify SPPV and GTPV from clinical samples of infected small ruminants without the need for further testing or confirmation. The nucleic acid extraction by novel modified microwave method enabled isolating DNA from scab biopsy samples and CAM positive samples, with the highest quality DNA being isolated in less than five minutes, and offers cheap fast extraction methods.

\section{DECLARATIONS}

\section{Authors' Contribution}

Gamil SG Zeedan, Ayman H. Mahmoud and Abeer M. Abdalhamed found research idea, planned the study design, performed data, and samples collection, performed laboratory works such as PCR, Real time PCR application and drafted the manuscript. Alaa A Ghazy and Khaled A Abd EL-Razik sharing in the conception of the research idea, sharing laboratory work, provided some reagents and materials and helped in manuscript preparation

\section{Competing interests}

The authors declared that they have no competing interests.

\section{Acknowledgements}

The authors are thankful to Veterinary research division, National Research Centre, Dokki, Egypt, for facilities and materials during this work. Department of Biotechnology and Food hygiene, Animal health instituted, Dokki, Egypt, for providing required facilities of Real-time PCR.

\section{REFERENCES}

Abd-Elfatah EB, El-Mekkawi MF, Bastawecy IM and Fawzi EM (2018). Identification and phylogentic analysis of sheep pox during an outbreak of sheep in Sharkia Governorate, Egypt. Genetics and Molecular Research, 17:1-12. DOI: http:// 10.4238/gmr16039901

Abdallah FM, El Damaty HM and Kotb GF (2018). Sporadic cases of lumpy skin disease among cattle in Sharkia province, Egypt: Genetic characterization of lumpy skin disease virus isolates and pathological findings. Veterinary World, 11: 1150-1158. DOI: http://10.14202/vetworld.2018.1150-1158

Aguilar-Torres FG, Rytel MW and Kagan IG (1967). Comparison of counterimmunoelectrophoresis (CIE) with other serologic tests in the detection of antibodies to Trypanosoma Cruzi. The American journal of tropical medicine and hygiene, 25: 667-670. DOI: // https:// 10.4269/ajtmh.1976.25.667

Aiello SE and Moses MA (2016). The Merck veterinary manual. 11th edition. Kenilworth, NJ: Merck Sheeppox and goatpox, pp. 869-70. Available at: www.cfsph.iastate.edu

Al-shabebi A, IEl-sabagh, EAbu-Elzein, Azaghaw A, Al-Naeem F and Housawi (2014). Molecular detection and phylogenetic analysis of sheep pox virus in Al Hassa of Eastern Province of Saudi Arabia Advances in Animal and Veterinary Sciences, 2S: 31-34. DOI: https:// 10.14737/journal.aavs/2014/2.2s.31.34

Assefa A (2017). Isolation and Identification of Sheep Pox from sheep and goats and Its Economic Importance in Adea Berga district, West Shoa zone (Doctoral dissertation, Addis Ababa University). Available at: https://hdl.handle.net/10568/90469

Atalla H and Alzuheir I (2019). Epidemiological study of Sheep and Goat pox Disease in Palestine during 2005-2017. International Journal of Current Microbiology and Applied Sciences, 8: 667-675. DOI: https:// 10.20546/ijcmas.2019.805.078

BenChehida F, Ayari-Fakhfakh E, Caufour P, Amdouni J, Nasr J, Messaoudi L, Haj Ammar H, Sghaier S, Bernard C et al. (2018) Sheep pox in Tunisia: Current status and perspectives. Transboundary and Emerging Diseases, 65:50-63. DOI: https:// 10.1111/tbed.12656

Bhanuprakash V, Venkatesan G, Balamurugan V, Hosamani M, Yogisharadhya R, Chauhan RS, Pande A, Mondal B and Singh RK (2010). Pox outbreaks in sheep and goats at Makhdoom (Uttar Pradesh), India: evidence of sheeppox virus infection in goats. Transboundary and emerging diseases, 57: 375-382. DOI: https:// 10.1111/tbed.12656

Bhanuprakash V, Hosamani M and Singh RK (2011). Prospects of control and eradication of capripox from the Indian subcontinent: a perspective. Antiviral Research. 91: 225-232. DOI: https:// 10.1111/j.1865-1682.2010.01158.x

Cohen J, Bererhi A, Ribero M, Vincet J and Delogneau J (1971). Electron microscopic study of the morphogenesis of sheep pox virus in tissue culture. The Annales de l'Institut Pasteur (Paris), 121: 569-577. PMID: 5169027

Fatima AT and El-Hussein AM (2017). Isolation and Identification of Camel Pox Virus from naturally infected camels in Elgadaref State, Sudan. Journal of Veterinary Science \& Medical Diagnosis, 6:.4-12. DOI: https:// 10.4172/2325-9590.1000235

Fahmy SR and Gaafar K (2016). Establishing the first institutional animal care and use committee in Egypt Ethics, and Humanities in Medicine, 11: 28. DOI: https:// 10.1007/s11356-018-3913-y

Fentie T, Fenta N, Leta S, Molla W, Ayele B, Teshome Y, Nigatu S and Assefa A (2017 ). Sero-prevalence, risk factors and distribution of sheep and goat pox in Amhara Region, Ethiopia. BMC Veterinary Research, 13: 385-393. DOI: https:// 10.1186/s12917-017-1312-0 
Gelaye E, Lamien CE, Silber R, Tuppurainen ES, Grabherr R and Diallo A (2013). Development of a cost-effective method for capripoxvirus genotyping using snapback primer and dsDNA intercalating dye. PloS one, 8: 10 e75971. DOI: https:// 10.1371/journal.pone.0075971

Gelaye E and Lamien CE (2019). Sheep and Goat Pox." In Transboundary Animal Diseases in Sahelian Africa and Connected Regions, 289-303. 2019. DOI: https:// 10.1007/978-3-030-25385-1_14

Hamouda1 F, Al-Hizab and El-Sabagh I (2017). Clinical, pathological and molecular diagnosis of sheeppox virus. Saudi Arabia Journal of Animal and Plant Sciences, 27: 91-97 DOI: https:// /10.1007/978-3-030-25385-1

Hosamani, M, Mondal B, Tembhurne PA, Bandyo-PadhyaySK, Singh RK and Rasool TJ (2004). Differentiation of sheep pox and goat poxviruses by sequence analysis and PCR-RFLP of P32 gene. Virus Genes, 29: 73-80. DOI: http// 10.4238/gmr16039901

Karapinar Z, Ilhan F, Dincer E and Yildirim S (2017). Pathology and phylogenetic analysis of capripoxvirus in naturally infected sheep with sheeppox virus. Pakistan Veterinary Journal, 37: 78-84. DOI: 1578528679--WVJ-1203 E4 (1).docx

Kumar B, Thakre BJ, Mathapati BS, Kalariya VA, SinghVK and Patbandha TK (2016) Advanced Laboratory Techniques in Livestock Disease Investigation, pp. 1-177. DOI: https://580ed6e808aef766ef10ea5c

Lafar S, Zro K, and Ennaji MM (2020). Capripoxvirus Diseases: Current updates and developed strategies for control. In Emerging and Reemerging Viral Pathogens, Academic Press, 635-655. DOI: https:// 10.1016/B978-0-12-819400-3.00028-4

Lamien CE, Le Goff C, Silber R, Wallace DB, Gulyaz V, Tuppurainen E, Madani H, Caufour P, Adam T et al. (2011). Use of the Capripoxvirus homologue of Vaccinia virus $30 \mathrm{kDa}$ RNA polymerase subunit (RPO30) gene as a novel diagnostic and genotyping target: development of a classical PCR method to differentiate Goat poxvirus from Sheep poxvirus. Veterinary microbiology, 149: 30-39. DOI: https:/ /10.1016/j.vetmic.2010.09.038

Mahmoud MA and Khafagi MH (2016). Detection, identification, and differentiation of sheep pox virus and goat pox virus from clinical cases in Giza Governorate, Egypt, Veterinary World, 9:1445-1449. DOI: https://10.14202/vetworld.2016.1445-1449

Manjunathareddy G, Sumana, K, Rizvan A, Revanaiah, Yogisharadhya P and Awadhesh (2017). Investigation of malignant form of sheep pox outbreak in fattening lambs in Mandya, Karnataka. Indian Journal of Veterinary Pathology, 41: 184. DOI: https:// 10.5958/097370X.2017.00045.1

Melendez JH (2016). Development and evaluation of microwave-accelerated and metal-enhanced fluorescence assays for detection of bacterial pathogens. University of Maryland, Baltimore County. DOI: http// 10.1109/TBME.2010.2066275

Page ID, Richardson M and Denning DW (2015). Antibody testing in aspergillosis. Medical mycology, 53:417-39. DOI: https:// 10.1093/mmy/myv020

Sambrook J, Fritsch EF and Maniatis T (1989). Molecular cloning: a laboratory manual (No. Edition. Cold spring harbor laboratory press. Available at: https://www.cabdirect.org/cabdirect /19901616061

Santhamani R, Yogisharadhya R, Venkatesan G, Shivachandra SB, Pandey AB and Ramakrishnan MA (2013). Detection and differentiation of sheep pox virus and goat pox virus from clinical samples using $30 \mathrm{kDa}$ RNA polymerase subunit (RPO30) gene based PCR. Veterinary World, 6: 923925. DOI: http:// 10.14202/vetworld.2013

Seesui K, Imtawil K, Chanetmahun P, Laummaunwai, and Boonmars T (2018). An alternative method for extracting plasmodium DNA from EDTA whole blood for malaria diagnosis. The Korean journal of parasitology. 1: 25-32. DOI: http: // 10.3347/kjp.2018.56.1.25

Sharma S, Nashiruddullah N, Ahmed JA and Berian (2019). Differential pathology of Capripox isolates in chicken embryonated eggs. International Journal of Current Microbiology and Applied Sciences, 8: 2485-2490. DOI: https:// 10.20546/ijcmas.2019.808.289

Shehbaz HA and Hassan IQ (2017). Phylogenetic analysis of sheep pox virus isolates based on P32 gene in Iraq. Journal of Entomology and Zoology Studies, 5: 704-708. Available at: http://www.entomoljournal.com/

Tassew A, Assefa A, Gelaye E, Bayisa B and Ftiwi M (2018). Identification and molecular characterization of lumpy skin disease virus in East Hararghe and East Shoa zone, Oromia Regional State 4: 1-16. DOI: http:// 10.20431/2455-2518.0403001

World Organization for Animal Health (OIE) (2017). Manual of diagnostic tests and vaccines for terrestrial animals [online]. Paris: OIE; 2017. Sheep pox and goat pox. Available at: http://www.oie.int/fileadmin/Home/eng/Health_standards/tahm/2.07.13_S_POX_G_POX.pdf. Accessed 2 Aug 2017.

Yan X., Chu YF, Wu GH, Zhao ZX, Li J, Zhu HX and Zhang Q (2012). An outbreak of sheep pox associated with goat poxvirus in Gansu province of China. Veterinary Microbiology, 156: 425-428. DOI: https:// 10.1016/j.vetmic.2011.11.015.

Yang F, Wang SS, Vaughan LM, Porter M and Rose E and Dickinson B (2019). Methods and compositions for direct chemical lysis. U.S. Patent 10,190,152. Available at: https://patents.google.com/patent/US10323267B2/en

Zangana IK and Abdullah MA (2013). Epidemiological, clinical and histopathological studies of lamb and kid pox in Duhok, Iraq. Bulgarian Journal of Veterinary Medicine, 16:133-138. Available at: https://scholar.google.com/scholar?hl=en\&as_sdt=0\%2C5\&as_

Zeedan GS, Allam AM, Nasr SM and Aballhamed AM (2014). Evaluation the efficacy of Egyptian propolis against parapox viruses by production of IFN-, TNF-and immunoglobulin in experimental rat. World Applied Sciences Journal, 31: 199-207. DOI: http// 10.5829/idosi.wasj.2014.31.02.82118

Zeedan GS, Abdalhamed AM, Ghoneim NH and Ghazy AA (2015). Isolation and molecular diagnosis of orf virus from small ruminants and human in Egypt. Journal of Antivirals and Antiretrovirals, 10: 12-17. DOI: http// 10.4172/jaa.1000113

Zeedan GSG, Mahmoud AH, Abdalhamed AM, Abd El-Razik KA, Khafagi MH and Abou Zeina HAA (2019). Detection of lumpy skin disease virus in cattle using real-time polymerase chain reaction and serological diagnostic assays in different governorates in Egypt in 2017, Veterinary World, 12: 1093-1100. DOI: http// 10.14202/vetworld.2019.1093-1100 